\section{Diclofenac sodium in biliary colic: a double blind trial}

There is evidence that prostaglandins play a part in the pathogenesis of biliary pain. ${ }^{2}$ Open trials have shown that non-steroidal antiinflammatory drugs can relieve biliary pain by inhibiting the synthesis of prostaglandins. ${ }^{34} \mathrm{We}$ report a double blind randomised trial of diclofenac sodium (Voltaren), a potent inhibitor of prostaglandin synthesis, versus placebo in biliary colic.

\section{Patients, methods, and results}

We studied 30 consecutive outpatients (14 men and 16 women; mean (SD) age $46(11.8)$ years) with gallstone disease, confirmed by ultrasonography or radiography or at operation, who complained of biliary colic. Patients were randomly treated under double blind conditions with either $75 \mathrm{mg}$ diclofenac sodium given intramuscularly or placebo and were followed up for 24 hours. All patients had given their informed consent.

Before the injection and 25 minutes afterwards patients estimated the intensity of their pain on a $100 \mathrm{~mm}$ analogue chromatic continuous scale on which $0 \mathrm{~mm}$ represented no pain and $100 \mathrm{~mm}$ represented unbearable pain. ${ }^{5}$ Every five minutes after the injection relief of pain was also assessed on a three point scale ( $1=$ no relief, $2=$ partial relief, $3=$ complete relief). Patients whose pain was not relieved 25 minutes after the injection and who asked for an analgesic were treated with $75 \mathrm{mg}$ diclofenac sodium intramuscularly, and relief of pain was registered using the three point scale 30 minutes later.

Fourteen patients were given diclofenac and 16 placebo. The two groups were similar for age, weight, sex, duration of pain, and initial intensity of pain according to the analogue scale. The median duration of pain before injection was three hours in the patients given diclofenac and four hours in those given placebo.

The table shows that partial or complete relief of pain was achieved 15 minutes after the injection in all patients given diclofenac and in two $(12.5 \%)$ of the 16 given placebo $\left(\chi^{2}\right.$ test, $\left.\mathrm{p}<0.001\right)$. Complete relief of pain was achieved 25 minutes after the injection in nine $(64 \%)$ of the patients given diclofenac and none of those given placebo $(p<0.01)$. Mean (SD) intensity of pain changed from $80.2(13.07) \mathrm{mm}$ on the analogue scale to $9.7(8.78) \mathrm{mm}$ 25 minutes after injection in the group given diclofenac (paired $t$ test, $\mathrm{p}<0.001$ ) and from $85.7(9.53)$ to $86.0(9.87) \mathrm{mm}$ in the group given placebo (NS). There was a significantly greater reduction of pain in the group given diclofenac compared with placebo (trend analysis, $F=85.48, p<0.001$ ).

During the 24 hour follow up period none of the patients given diclofenac but all of those given placebo needed an injection of $75 \mathrm{mg}$ diclofenac after 25 minutes due to persistent and severe pain. Of the 16 patients treated with diclofenac, nine had partial and seven complete relief of pain within 30 minutes. No side effects were experienced.

Relief of pain after injection of diclofenac sodium or placebo in patients with biliary colic

\begin{tabular}{ccccccccc}
\hline \multirow{2}{*}{$\begin{array}{c}\text { Minutes } \\
\text { after } \\
\text { injection }\end{array}$} & \multicolumn{2}{c}{ Diclofenac $(n=14)$} & & \multicolumn{3}{c}{ Placebo $(n=16)$} \\
\cline { 2 - 4 } \cline { 7 - 8 } & relief & $\begin{array}{c}\text { Partial } \\
\text { relief }\end{array}$ & $\begin{array}{c}\text { Complete } \\
\text { relief }\end{array}$ & & $\begin{array}{c}\text { No } \\
\text { relief }\end{array}$ & $\begin{array}{c}\text { Partial } \\
\text { relief }\end{array}$ & $\begin{array}{c}\text { Complete } \\
\text { relief }\end{array}$ \\
\hline 5 & 13 & 1 & 0 & & 15 & 1 & 0 \\
10 & 3 & 10 & 1 & & 16 & 0 & 0 \\
15 & 0 & 11 & 3 & & 14 & 2 & 0 \\
20 & 0 & 7 & 9 & & 16 & 0 & 0 \\
25 & 0 & 5 & 9 & & 16 & 0 & 0
\end{tabular}

\section{Comment}

This trial confirms the results of open trials carried out with non-steroidal anti-inflammatory drugs. Our data show that diclofenac sodium is more effective than placebo in relieving the pain associated with gallstone disease, which indirectly suggests that prostaglandins play a part in the pathogenesis of acute biliary pain.

In our clinical experience the extent of analgesia obtained in this trial was superior to that obtained with anticholinergic agents. In fact, anticholinergic drugs yield questionable results in obstructive lithiasis, and to our knowledge their use in this condition is not supported by results of a controlled trial. As opiates are contraindicated in the treatment of biliary colic because of their spasmogenic action on the biliary tract, potent inhibition of prostaglandin synthesis such as diclofenac sodium may offer a good alternative and perhaps be the drugs of first choice in the treatment of this common painful condition.

${ }^{1}$ Heintz CK, Leinesser W, Peterson KU, Heindenre1ch O. Triphasic effect of prostaglandins E1, E2 and F1 alpha on the fluid transport of isolated gall-bladder of guinea pigs. Prostaglandins 1975;9:309-22.
2 Morton IKM, Saverymuttu SH, Wood JH, Wood JR. Inhibition by prostaglandins of fluid transport in the isolated gall-bladder of the guinea pig [Proceedings]. Br F Pharmacol 1974;50:460P.

3 Thornell E, Jansson R, Kral JG, Svanvik J. Inhibition of prostaglandin synthesis as a treatment for biliary pain. Lancet $1979 ; \mathrm{i}: 584$.

${ }^{4}$ Lundstam S, Tveit E, Kral JG. Prostaglandin synthesis inhibition by diclofenac-Na in biliary pain [Abstract]. Eur $\mathcal{F}$ Clin Invest 1983;13:A1.

${ }^{5}$ Grossi E, Borghi C, Cerchiari EL, Della Puppa T, Francucci B. Analogue chromatic continuous scale (ACCS): a new method for pain assessment. Clinical and Experimental Rheumatology 1983;1:337-40.

(Accepted 30 December 1983)

Ospedale Regionale di Varese, 21100 Varese, Italy

M BROGGINI, MD, internist, department of general medicine

E CORBETTA, MD, consultant in emergency medicine

Medical Department, Ciba-Geigy, Origgio, Varese, Italy

E GROSSI, MD, head of rheumatism and pain research group

C BORGHI, PHD, medical adviser, rheumatism and pain research group (also professor at the Postgraduate School of Toxicology)

Correspondence to: Dr M Broggini.

\section{Isolated palsy of the hypoglossal nerve after central venous catheterisation}

We report an isolated lesion of the hypoglossal nerve in a patient after central venous catheterisation.

\section{Case report}

A 50 year old man presented for elective coronary artery bypass grafting. He had no preoperative symptoms either of cranial nerve dysfunction or of infectious processes within the upper respiratory tract. After induction of anaesthesia and routine endotracheal intubation cannulation of the right internal jugular vein was performed by the high technique with a medial approach. An over the needle cannula (Abbocath-T 14 gauge, $5 \frac{1}{2}$ inches, No 4535-84) was inserted without difficulty at the midpoint of the medial border of the sternocleidomastoid muscle, lateral to the carotid artery. The cannula was used for monitoring the central venous pressure and for administering drugs during the operation. He was electively ventilated over night and extubated the following morning. From the time he began to take fluids and solids by mouth he reported difficulty in moving his tongue around his mouth, with associated trouble in mastication. Apart from this he remained clinically well. Examination showed signs of palsy of the right hypoglossal nerve with no other associated neurological deficit. In the subsequent eight weeks his tongue function improved progressively.

\section{Comment}

The hypoglossal nerve passes downwards between the internal carotid artery and the internal jugular vein, becoming superficial below the posterior belly of the digastric muscle, where it is covered by the common facial vein and deep investing fascia. After crossing the occipital artery it is held down by the lower sternomastoid branch of the occipital artery and passes forward across both internal and external carotid arteries to supply the tongue muscles. The nerve therefore lies close to the internal jugular vein and internal carotid artery at the level of the site of skin puncture used. Tethering of the hypoglossal nerve by the occipital artery or its lower sternomastoid branch is well documented, ${ }^{1}$ and anatomical variants could predispose it to trauma by percutaneous instrumentation. Reichert et al described a case of peripheral palsy of the right hypoglossal nerve after the use of a similar technique, with the difference that the cannula was passed through the sternomastoid muscle. ${ }^{2}$ They suggested that extension and rotation of the neck to facilitate puncture, and application of a pressure bandage after a failed attempt, were probable risk factors. Trauma around the carotid artery associated with carotid endarterectomy is a well known cause of injury to the nerve and is probably related to overzealous retraction. ${ }^{3}$ Agnoli and Strauss suggested that vigorous intubation during direct laryngoscopy may cause paresis of the lingual and hypoglossal nerves by a pressure effect in the parapharyngeal space. ${ }^{4}$

Despite this rare complication of a routine procedure, which may 
have been due to direct trauma or haematoma around an aberrantly coursing hypoglossal nerve, we still consider high puncture of the internal jugular vein to be a useful approach.

We thank Mr F P Shabbo and Dr J E Brett for permission to report details of their patient.

'Scotti G, Melancon D, Olivier A. Hypoglossal paralysis due to compression by a tortuous internal carotid artery in the neck. Neuroradiology 1978; $14: 263-5$.

${ }^{2}$ Reichert W, Mehler D, Otten B. Isolated peripheral twelfth nerve paresis following puncture of the internal jugular vein. Anaesthetist $1981 ; 30$ : 46.

${ }^{3}$ Dehn TCB, Taylor GW. Cranial and cervical nerve damage associated with carotid endarterectomy. Br 7 Surg 1983;70:365-8.

- Agnoli A, Strauss P. Isolated paresis of the nervus hypoglossus and combined paresis of the nervus hypoglossus and the nervus lingualis following intubation and direct laryngoscopy. HNO 1970;18:237-9.

(Accepted 30 December 1983)

Regional Cardiothoracic Centre, Brook General Hospital, London SE18 21W

HEIKKI B WHITTET, $\mathrm{MB}$, Bs, senior house officer in cardiothoracic surgery

MICHAEL J BOSCOE, FFARCS, senior registrar in anaesthetics

Correspondence to: Dr H B Whittet.

\section{Persistence of rubella antibody 8-18 years after vaccination}

Immunity induced by rubella vaccines must persist throughout the childbearing years, a period of about 30 years. We have reported persistence of rubella antibody at values exceeding $15000 \mathrm{IU} / 1$ in $89.4 \%$ of volunteers vaccinated six to 16 years earlier. ${ }^{1}$ We now present the results of retesting these vaccinees two years later.

\section{Methods and results}

Serum samples were obtained between March and June 1983 from 93 of the 123 vaccinees previously tested. ${ }^{1}$ Sixty three volunteers had been vaccinated with RA27/3, HPV77-DE5, Cendehill, or a Japanese vaccine To-336 eight to 10 years previously while student nurses at St Thomas's Hospital, London. Thirty volunteers had been vaccinated with either RA27/3 or Cendehill vaccine 13-18 years previously while student nurses at The Hospital for Sick Children, London. Eight of these 93 vaccinees had low antibody values $(<15000 \mathrm{IU} / \mathrm{l})$ when tested in 1981 and were subsequently revaccinated with RA27/3 by the intranasal route. ${ }^{2}$

Sera were tested for rubella antibodies by single radial haemolysis ${ }^{3}$ and for rubella specific IgG by radioimmunoassay. ${ }^{4}$ Sera were compared with the standard serum containing 15000 IU rubella antibody per 1 , which is accepted as indicating a satisfactory level of immunity. ${ }^{3}$ Tests of significance were carried out using unpaired $t$ tests.

Of the 93 vaccinees tested, two were seronegative (no zone) by single radial haemolysis (table), although both had antibodies by radioimmunoassay (titres 20 and 320). One of these women had been among the group of eight with antibody values below $15000 \mathrm{IU} / 1$ who had been challenged with RA27/3 intranasally in 1981 . The remaining seven had antibody values exceeding $15000 \mathrm{IU} / 1$ by both single radial haemolysis and radioimmunoassay when tested two years after challenge. Eight to 10 years after vaccination the geometric mean titre of To-336 vaccinees measured by radioimmunoassay was higher than that of the other vaccine groups (table) but this difference was not significant $(p>0.05)$. Although volunteers given Cendehill vaccine 13-18 years previously had a lower geometric mean titre than those given the vaccine eight to 10 years before, this difference was not significant $(p>0.05)$. The two groups of RA27/3 vaccinees had a similar geometric mean titre.

\section{Comment}

We were reassured to find that antibodies ( $>15000 \mathrm{IU} / \mathrm{l})$ had persisted in most $(98 \%)$ of the rubella vaccinees eight to 18 years after vaccination. Nevertheless, in our previous study 13 of the 123 vaccinees $(10.6 \%)$ had antibody values below $15000 \mathrm{IU} / \mathrm{l}$, even when tested by radioimmunoassay. ${ }^{1}$

Of the two women with no antibody detectable by single radial haemolysis, one, who had a radioimmunoassay titre of $20(<15000$
Immune state and geometric mean antibody titres 8-18 years after rubella vaccination (that is, in 1983)

\begin{tabular}{|c|c|c|c|c|}
\hline \multirow{2}{*}{ Vaccine received } & \multirow{2}{*}{ No } & \multicolumn{2}{|c|}{$\begin{array}{c}\text { No }(\%) \text { with antibodies } \\
<15000 \text { IU } / 1\end{array}$} & \multirow{2}{*}{$\underset{\text { RIA }}{\text { GMT }}$} \\
\hline & & SRH & RIA & \\
\hline \multicolumn{5}{|c|}{ Volunteers from St Thomas's Hospital vaccinated $8-10$ years previously } \\
\hline RA27/3 & 26 & 0 & 0 & 1150 \\
\hline Cendehill & 12 & & 0 & 1260 \\
\hline $\begin{array}{l}\text { HPV77-DE5 } \\
\text { To-336 }\end{array}$ & $\begin{array}{l}14 \\
11\end{array}$ & $\begin{array}{l}1(7 \cdot 1) \\
0\end{array}$ & $\begin{array}{l}0 \\
0\end{array}$ & $\begin{array}{l}1159 \\
1868\end{array}$ \\
\hline \multicolumn{5}{|c|}{$\begin{array}{l}\text { Volunteers from The Hospital for Sick Children } \\
\text { vaccinated 13-18 years previously }\end{array}$} \\
\hline $\begin{array}{l}\text { RA27/3 } \\
\text { Cendehill }\end{array}$ & $\begin{array}{l}12 \\
18\end{array}$ & ${ }_{0}^{1}(8 \cdot 3)$ & $1_{0}^{1(8 \cdot 3)}$ & $\begin{array}{r}1140 \\
746\end{array}$ \\
\hline Total vaccinees & 93 & $2(2 \cdot 1)$ & $1(1 \cdot 0)$ & 1180 \\
\hline
\end{tabular}

SRH $=$ Single radial haemolysis. RIA $=$ Radioimmunoassay. $\quad G M T=$ Geometric mean titre.

IU/1), had received RA27/3 13 years previously. This woman had had antibody values below $15000 \mathrm{IU} / 1$ by both single radial haemolysis and radioimmunoassay when tested in 1981; she was not revaccinated at that time as she was planning pregnancy. The other woman who was seronegative by single radial haemolysis had a radioimmunoassay titre of 320 (>15000 IU/1); this woman had received HPV77-DE5 10 years previously and was revaccinated with RA27/3 in 1981 as she had no antibodies detectable by single radial haemolysis and had a radioimmunoassay titre of $80(<15000 \mathrm{IU} / \mathrm{l})$. Although in 1983 she had a radioimmunoassay titre of 320 , single radial haemolysis showed that her antibodies had again declined to undetectable values. Although antibodies detectable by radioimmunoassay but not by single radial haemolysis may be associated with protection, it has previously been shown that viraemia may occur in patients with antibody values below $15000 \mathrm{IU} / 1 .{ }^{25}$ Until the antibodies conferring immunity have been more accurately identified, it is generally advisable to offer vaccination to women with antibody values below $15000 \mathrm{IU} / \mathrm{l}$ as determined by single radial haemolysis.

Although these results are encouraging, they should not detract from the importance of continued long term surveillance in order to determine persistence of antibody, booster antibody responses, and outcome of pregnancies among women who have been given different rubella vaccines and may have been exposed to rubella. Geometric mean titres should be interpreted with caution, since they may not merely reflect the magnitude of the immune response to vaccine but may also be a reflection of booster antibody responses due to exposure to rubella in the community. We aim to collect further blood samples from the volunteers in this study in order to test the frequency of this phenomenon.

${ }^{1}$ O'Shea S, Best JM, Banatvala JE, Marshall WC, Dudgeon JA. Rubella vaccination: persistence of antibodies for up to 16 years. Br Med $\mathcal{F}$ $1982 ; 285: 253-5$

2 O'Shea S, Best JM, Banatvala JE. Viremia, virus excretion, and antibody responses after challenge in volunteers with low levels of antibody to rubella virus. $\mathcal{F}$ Infect Dis $1983 ; 143: 639-47$.

${ }^{3}$ Kurtz JB, Mortimer PP, Mortimer PR, Morgan-Capner P, Shafi MS, White GBB. Rubella antibody measured by radial haemolysis. Characteristics and performance of a simple screening method for use in diagnostic laboratories. $\mathcal{F}$ Hyg (Camb) 1980;84:213-22.

4 Best JM, Harcourt GC, Druce A, Palmer SJ, O'Shea S, Banatvala JE. Rubella immunity by four different techniques: results of challenge studies. F Med Virol 1980;5:239-47.

5 Balfour HH, Groth KE, Edelman CK, Amren DP, Best JM, Banatvala JE. Rubella viraemia and antibody responses after rubella vaccination and reimmunisation. Lancet 1981 ; i :1078-80.

(Accepted 6 fanuary 1984)

Department of Virology, St Thomas's Hospital and Medical School, London SE1 7EH

SIOBHAN O'SHEA, MIBIOL, research assistant

JENNIFER M BEST, PHD, MRCPATH, senior lecturer

J E BANATVALA, MD, FRCPATH, professor of clinical virology

The Hospital for Sick Children, Great Ormond Street, London WC1 W C MARSHALL, MD, FRACP, consultant paediatrician. (Dr Marshall died on 24 October 1983)

J A DUDGEON, MD, FRCP, emeritus professor of microbiology

Correspondence to: Professor J E Banatvala. 